\title{
DETERMINATION OF VIRAL TROPISM BY GENOTYPING AND PHENOTYPING ASSAYS IN BRAZILIAN HIV-1-INFECTED PATIENTS
}

Liã Bárbara ARRUDA(1,2), Marilia Ladeira de ARAÚJO(2), Maira Luccia MARTINEZ(2), Claudio Roberto GONSALEZ(3), Alberto José da Silva DUARTE(2), Eoin COAKLEY(4), Yolanda LIE(4) \& Jorge CASSEB(1,2)

\begin{abstract}
SUMMARY
The clinical application of CCR5 antagonists involves first determining the coreceptor usage by the infecting viral strain. Bioinformatics programs that predict coreceptor usage could provide an alternative method to screen candidates for treatment with CCR5 antagonists, particularly in countries with limited financial resources. Thus, the present study aims to identify the best approach using bioinformatics tools for determining HIV-1 coreceptor usage in clinical practice. Proviral DNA sequences and Trofile results from 99 HIV-1-infected subjects under clinical monitoring were analyzed in this study. Based on the Trofile results, the viral variants present were $81.1 \%$ R5, 21.4\% R5X4 and 1.8\% X4. Determination of tropism using a Geno2pheno analysis with a false positive rate of $10 \%$ gave the most suitable performance in this sampling: the R5 and X4 strains were found at frequencies of $78.5 \%$ and $28.4 \%$, respectively, and there was $78.6 \%$ concordance between the phenotypic and genotypic results. Further studies are needed to clarify how genetic diversity amongst virus strains affects bioinformatics-driven approaches for determining tropism. Although this strategy could be useful for screening patients in developing countries, some limitations remain that restrict the wider application of coreceptor usage tests in clinical practice.
\end{abstract}

KEYWORDS: HIV-1; Tropism; Brazil; V3 loop.

\section{INTRODUCTION}

Maraviroc, which blocks virus entry by binding to the CCR5 coreceptor, was the first CCR5 antagonist approved for clinical use. This molecule has been widely recommended for controlling HIV infection with a low level of drug resistance $e^{6,14,28}$. However, the use of this drug class in clinical practice requires the assessment of the coreceptor usage before and during the treatment ${ }^{20}$. Studies comparing the efficiency of phenotypic and genotypic assays, in order to develop widely applicable strategies useful in developing countries, have raised several issues regarding the determination of HIV-1 tropism ${ }^{7,18}$.

Although phenotypic tropism tests (PTT) are considered the gold standard for determining coreceptor usage, their wide application in clinical practice is limited mainly by their high cost and the logistical restrictions of the procedures ${ }^{1,7}$. In this context, programs able to predict coreceptor usage based on $\mathrm{V} 3$ sequences have provided a suitable alternative for screening candidates for CCR5 antagonist therapy ${ }^{23}$.

Several bioinformatics protocols for tropism prediction have been published. They assess tropism based on amino acids sequences from the V3 loop, which is known to be an important binding region on the gp120 envelope protein ${ }^{19,23}$. Because the use of phenotypic assays is still limited, the European Guidelines have encouraged the application of bioinformatics programs in coreceptor usage determination ${ }^{27}$. However, due to the intrinsic differences of each predictive system, divergent outputs are expected and remain a reason for concern in the wider application of this approach ${ }^{9,15,19,23-24}$.

The aim of this study was to examine the use of the Geno2pheno program for tropism prediction and determine its usefulness as an alternative method in clinical practice for screening CCR5 antagonist therapy candidates for the first time in Brazil.

\section{MATERIAL AND METHODS}

Sampling: Sample collection occurred between July 2009 and October 2010, from the HIV outpatient clinic ADEE3002/HCFMUSP. Only 99 from this cohort showed the minimum plasmatic RNA viral load necessary to qualify for the Trofile assay (> 1000 copies $/ \mathrm{mL}$, as recommended by Monogram Biosciences, San Francisco, CA). The written informed consent for collecting blood samples and the protocol for this study were approved by the Ethical Research Board of the

(1) Institute of Tropical Medicine of Sao Paulo, University of Sao Paulo, Dr. Eneas de Carvalho Aguiar Avenue 470, Building II, Sao Paulo, SP. Brazil.

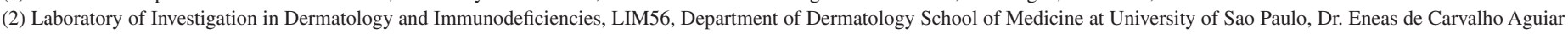
Avenue 470, Building II, $3^{\text {rd }}$ floor, Sao Paulo, SP, Brazil.

(3) HIV Out-clinic, Ambulatory of Secondary Immunodeficiencies, ADEE3002, Department of Dermatology, Hospital of Clinics at School of Medicine at University of Sao Paulo.

(4) Monogram Biosciences, Inc., 345 Oyster Point Blvd. South San Francisco, CA 94080-1913, USA.

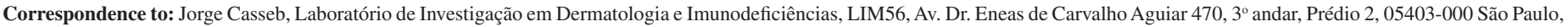
SP, Brasil. Tel.: +55 113061 7194. Fax: +55 113081 7190. E-mail: jcasseb10@gmail.com 
ARRUDA, L.B.; ARAÚJO, M.L.; MARTINEZ, M.L.; GONSALEZ, C.R.; DUARTE, A.J.S.; COAKLEY, E.; LIE, Y. \& CASSEB, J. - Determination of viral tropism by genotyping and phenotyping assays in Brazilian HIV-1-infected patients. Rev. Inst. Med. Trop. Sao Paulo, 56(4): 287-90, 2014

Hospital das Clinicas, Faculdade de Medicina da Universidade de São Paulo (Cappesq - HC/FMUSP, number 08/0108).

Subjects: A total of 99 patients under clinical monitoring were included in this study, of whom 29 (29.3\%) were females and $70(70.7 \%)$ were males. With respect to antiretroviral therapy, $62(62.6 \%)$ patients were drug-naïve, and 37 (37.4\%) were under HAART. Only subjects being treated with nucleoside and non-nucleoside reverse transcriptase inhibitors (NRTI and NNRTI) and protease inhibitors (PI) were studied.

After signing the informed consent form, $15 \mathrm{~mL}$ of venous blood was collected in EDTA-treated tubes from each patient. Plasma samples were separated and stored at $-70{ }^{\circ} \mathrm{C}$ until their shipment to Monogram Biosciences to perform the Trofile assay. Peripheral blood mononuclear cells (PBMCs) were isolated from blood samples by Ficoll-Hypaque density gradient centrifugation and stored at $-70{ }^{\circ} \mathrm{C}$ until use. DNA was extracted from PBMCs using the GFX Genomic Blood DNA Purification Kit (GE Healthcare, Little Chalfont, UK) according to the manufacturer's instructions.

The HIV-1 plasmatic viral load was measured using the Versant HIV RNA 3.0 Assay (bDNA) (Siemens Healthcare Diagnostics, San Francisco, USA), and CD4+/CD8+ T cell counts were determined by flow cytometry. These data were collected during routine clinical monitoring of patients and were obtained from the laboratory database.

In addition, 185 sequences containing known coreceptor sequence variations were obtained from the HIV Sequence Database (www.hivweb.lanl.gov) to assess the application of genotypic tropism test (GTT) in identifying different HIV-1 variants. Only V3 sequences with 35 amino acids were evaluated; sequences with 34 or 36 amino acids were excluded. All deposited sequences originating in Brazil were included, and at least $5 \%$ of the sequences for each group were selected from other countries of origin (Table 1).

Table 1

Distribution of HIV database sequences by subtype and phenotypic tropism

\begin{tabular}{lcccc}
\hline Subtype & R5 & R5X4 & X4 & Total \\
\hline B & 115 & 18 & 13 & 146 \\
C & 23 & 7 & 5 & 35 \\
F1 & 2 & 1 & 1 & 4 \\
\hline Total & 140 & 26 & 19 & $\mathbf{1 8 5}$ \\
\hline
\end{tabular}

V3 region amplification and sequencing: The V3 region was amplified by nested polymerase chain reaction (PCR) using the previously described outer primers ED5/ED12 and inner primers ED31/ED33 ${ }^{4}$. The PCR using the outer primers was performed with the following steps: one cycle of $94{ }^{\circ} \mathrm{C}$ for one min; 35 cycles of $94{ }^{\circ} \mathrm{C}$ for $45 \mathrm{sec}, 55^{\circ} \mathrm{C}$ for $45 \mathrm{sec}$, and $72{ }^{\circ} \mathrm{C}$ for two min; and a final extension cycle of $72{ }^{\circ} \mathrm{C}$ for $10 \mathrm{~min}$. The PCR using the inner primers was performed with the following steps: one cycle of $94{ }^{\circ} \mathrm{C}$ for one min; 35 cycles of $94{ }^{\circ} \mathrm{C}$ for one min, $55^{\circ} \mathrm{C}$ for one min and $72{ }^{\circ} \mathrm{C}$ for one min and $30 \mathrm{sec}$; and a final extension cycle of $72{ }^{\circ} \mathrm{C}$ for $10 \mathrm{~min}$. The $50-\mu \mathrm{L}$ reaction mixtures contained $2 \mathrm{mM} \mathrm{MgCl}, 2 \mu \mathrm{M}$ of each primer, $0.2 \mathrm{mM}$ of each dNTP, $1 \mathrm{U}$ Taq DNA polymerase and $5 \mu \mathrm{L}$ of extracted DNA for the outer PCR or $5 \mu \mathrm{L}$ of PCR product for the inner PCR.
The inner PCR products were purified using the QIAquick PCR fragment purification kit (Qiagen, Hilden, Germany) following the manufacturer's instructions. The sequencing reaction was carried out using the ABI Prism Big Dye Terminator v.3.1 Cycle Sequencing Ready Reaction Kit (Applied Biosystems, Foster City, USA), adding 20-100 ng of amplified and purified product and each inner PCR primer at $1 \mu \mathrm{M}$. The reaction was carried out according to the manufacturer's instructions, and the sequencing was performed using the ABI Prism 3100 system (Applied Biosystems, Foster City, USA). The resulting nucleotide sequences were edited using SeqScape Software v.2.6 (Applied Biosystems).

HIV-1 envelope subtyping was performed by manual phylogenetic analysis using the 2008 Alamos reference dataset (available at http://www.hiv.lanl.gov/content/sequence/NEWALIGN/align.html). Sequences were aligned and edited, and a tree was constructed with the Neighbor-Joining method and the Maximum Composite Likelihood model with 1000 bootstrap replicates using the MEGA v.5 package ${ }^{25}$.

Tropism determination: Coreceptor usage was determined using the Geno2pheno ${ }_{\text {[coreceptor] }}$ bioinformatics tool $(\mathrm{G} 2 \mathrm{P})^{10}$. False positive rates (FPR) were $10 \%$ for the proviral DNA sequences obtained in this study or $20 \%$ for clonal and clinical data.

The Trofile Coreceptor Tropism Assay (Monogram Biosciences, San Francisco, USA) was performed on plasma samples from patients showing viral load $>1000$ copies $/ \mathrm{mL}$.

\section{RESULTS}

Comparison between PTT and GTT: From the 99 samples sent for analysis with the Trofile assay, $55(55.6 \%)$ were identified as R5 viruses, $22(22.2 \%)$ were R5X4, and only one (1\%) sample showed tropism to the CXCR 4 coreceptor. The Trofile assay was unable to generate results for $21(21.2 \%)$ samples. Therefore, the coreceptor prevalence within the assayable sample population was 70.5\% (55/78) R5, 28.3\% (22/78) R5X4 and $1.3 \%(1 / 78) \mathrm{X} 4$ strains.

Readable sequences were obtained from 70 proviral DNA sequences, resulting in the generation of both Trofile and G2P results for 56 samples. These matched sample measures allowed for sensitivity and specificity testing, which showed that a FPR of $10 \%$ gave the highest sensitivity and specificity (Table 2).

Table 2

Sensitivity and specificity test for Geno2pheno ${ }_{\text {[coreceptor] }}$ false positive rates in prediction of CXCR4 coreceptor usage

\begin{tabular}{lcc}
\hline G2P FPR & Sensitivity $(\%)$ & Specificity $(\%)$ \\
\hline $10 \%$ & 54.5 & 84.4 \\
$20 \%$ clinical data & 50.0 & 82.6 \\
$20 \%$ clonal data & 34.8 & 68.1 \\
\hline
\end{tabular}

Note: G2P FPR: Geno2pheno ${ }_{\text {[coreceptor] }}$.

Based on the G2P FPR of 10\%, 55 (78.5\%) and $15(21.4 \%)$ of the 70 sequences obtained in this study were predicted to be R5 and X4 strains, respectively. There were no differences between the Trofile 


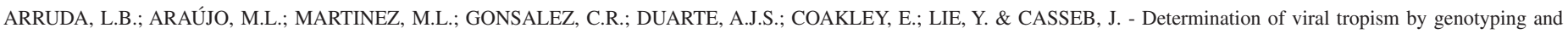
phenotyping assays in Brazilian HIV-1-infected patients. Rev. Inst. Med. Trop. Sao Paulo, 56(4): 287-90, 2014.

results $(\mathrm{R} 5=70.5 \% ; \mathrm{X} 4$ and $\mathrm{R} 5 \mathrm{X} 4=29.5 \%)$ and $\mathrm{G} 2 \mathrm{P}$ results found for this population.

Envelope subtyping was performed on the sequences obtained in this study. Only B $(n=46), C(n=2)$ and F1 $(n=8)$ subtypes were found, and it was not possible to identify any recombinant forms. Tropism prediction showed good accuracy regardless of the subtype, generating concordances between the Trofile and G2P results of $76.1 \%$ for subtype B samples, $100 \%$ for subtype C and $87.5 \%$ for subtype F1. Due to the small number of clinical samples in our study, a dataset containing 185 sequences from the Los Alamos HIV-1 sequence database was also analyzed. The prediction accuracy for the samples in this dataset was represented by concordances between the Trofile and G2P results of $88.3 \%$ for subtype B, $88.6 \%$ for subtype C and $100 \%$ for subtype F1 both sequences available in this database.

\section{DISCUSSION}

Phenotypic tropism tests (PTT) still represent the gold standard in tropism determination, but high cost and logistical restrictions are significant barriers preventing the wide application of these assays, particularly in developing countries ${ }^{7,23}$. Thus, the adoption of bioinformatics tools for determining coreceptor usage could provide a more accessible alternative for screening candidates for CCR5 antagonist therapy ${ }^{19,23}$.

The phenotyping test has some limitations in the clinical setting. While the commercially available Trofile assay is the most widely used phenotypic test ${ }^{1,7}$ and provides accurate determination of HIV tropism, it was unable to generate results for $21 \%$ of the samples in this study. An additional important limitation of the Trofile assay is the requirement that samples have a minimum plasmaviral load of 1000 copies $/ \mathrm{mL}$. Based on studies that identified similar tropism behavior in $75 \%$ to $90 \%$ of sequences from plasma and PBMCs, using proviral DNA as the source of viral genetic material could be the most reliable option for obtaining V3 sequences. Moreover, X4 viruses were detected more frequently in DNA samples from PBMCs than in RNA samples from plasma ${ }^{13,20,28}$. In fact, the Trofile test is mostly used in clinical trials and, in the meantime, has been replaced in the clinical setting by genotyping tests (at least in Europe). Furthermore, the Trofile test is not an entirely phenotypic assay, as a library of V3 loop sequences of HIV-RNA from the test sample is prepared by PCR amplification. There is bias in this PCR amplification, as is in any PCR. Only the read out of the Trofile test is phenotypic. In contrast, the MT2 assay is entirely phenotypic. Bias is also present in population based genotypic testing by the PCRs and the sequencing reactions used.

Bulk sequencing of proviral DNA is an intrinsically limited technique, because it produces a consensus sequence from dominant strains within the viral quasispecies ${ }^{7,19}$. Although it has been suggested that this problem could be mitigated by increasing the number of replicate sequences produced from each sample, this modification also increases the method's costs and time required and could further limit its use, particularly in countries with restricted financial resources ${ }^{7,11}$. The present study aimed to develop an accurate and cost-effective strategy for applying tropism testing in clinical practice. Although the European Guidelines recommend performing G2P with an FPR of $10 \%$ for triplicate samples and $20 \%$ for samples with a single sequence ${ }^{27}$, the present study's sensitivity and specificity tests showed that a G2P FPR $=10 \%$ is the best significance level, even for single sequences (Table 2).

This study showed that the concordance between PPT and GTT was also high for different subtypes (mean of concordance $=88 \%$ ), and this finding was confirmed by testing a large dataset from the Los Alamos Sequence Database (mean of concordance $=92 \%$ ). These results corroborate previous studies that showed $80-90 \%$ agreement between phenotypic and genotypic tests for determining tropism ${ }^{2,16-17,26}$. Despite the high concordance between the phenotypic and genotypic assays, there has been disagreement between the results generated by different bioinformatics-based assays, and several approaches to improving these

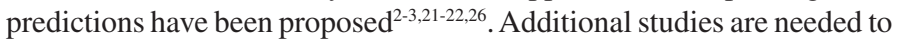
determine if viral sequences in the Brazilian patient population might be so distinct as to invalidate their analysis with available bioinformatics tools, which derive their datasets mainly from sequences found in patients from the USA and European countries.

Furthermore, while the determination of HIV-1 tropism has focused on the V3 loop, other features of gp120 could influence virus affinity for a particular coreceptor, including $\mathrm{N}$-glycosylation sites and variations in extensions of the V1/V2 region ${ }^{8,12}$. Information on the three-dimensional structure of the V3 loop and clinical and laboratory data from patients, such as T cells counts and viral load, could also substantially improve tropism predictions ${ }^{19}$.

\section{CONCLUSIONS}

The application of bioinformatics tools in coreceptor usage determination has been widely studied and could provide an alternative approach in clinical practice for screening candidates for CCR5 antagonist therapy, especially in cases where confirmatory assays for coreceptor usage determination are unavailable. This study showed that G2P analysis of sequences from PBMCs with an FPR of $10 \%$ could be the most suitable alternative approach for determining tropism, although this approach should be tested in a nationwide study to determine how HIV genetic diversity influences the findings.

\section{RESUMO}

\section{Determinação do tropismo viral por ensaios genotípicos e fenotípicos em pacientes brasileiros infectados por HIV-1}

A aplicação clínica dos antagonistas de CCR5 envolve em primeiro lugar determinar o uso de co-receptor pela cepa viral infectante. Programas de bioinformática que prevêem o uso co-receptor poderiam fornecer um método alternativo para selecionar candidatos para o tratamento com os antagonistas do CCR5, particularmente em países com poucos recursos financeiros. Assim, o presente estudo teve por objetivo identificar a melhor abordagem utilizando ferramentas de bioinformática para determinar qual o tipo de co-receptor do HIV-1 que poderia ser usado na prática clínica. Sequências de DNA proviral e Trofile resultados a partir de 99 pacientes infectados pelo HIV-1 sob monitorização clínica foram avaliadas. Com base nos resultados do Teste Trofile, as variantes virais presentes eram R5 (81,1\%), R5X4 (21,4\%) e X4 (1,8\%). Determinação do tropismo pela análise do Geno2pheno, com taxa de falso positivos de $10 \%$ apresentou desempenho mais adequado para esta amostragem: as cepas R5 e X4 foram encontradas 
ARRUDA, L.B.; ARAÚJO, M.L.; MARTINEZ, M.L.; GONSALEZ, C.R.; DUARTE, A.J.S.; COAKLEY, E.; LIE, Y. \& CASSEB, J. - Determination of viral tropism by genotyping and phenotyping assays in Brazilian HIV-1-infected patients. Rev. Inst. Med. Trop. Sao Paulo, 56(4): 287-90, 2014

em frequências de $78,5 \%$ e $28,4 \%$, respectivamente, e foi de $78,6 \%$ a concordância entre os resultados fenotípicos e genotípicos. Mais estudos são necessários para esclarecer como a diversidade genética entre as cepas do vírus afeta abordagens baseadas na determinação do tropismo pelas ferramentas de bioinformática. Embora esta estratégia possa ser útil para o rastreio de pacientes em países em desenvolvimento, permanecem algumas limitações que restringem a aplicação mais ampla para utilização de testes de co-receptor na prática clínica.

\section{ACKNOWLEDGEMENTS}

We thank all patients who participated in this study. We also thank Rosangela Araujo and Noemia Orii for performing the flow cytometry experiments, José Eduardo Martins for the determination of HIV-1 viral load and the financial support from FAPESP (08/58138-0; 08/51265-6; 10/00222-5); FFM; CNPq.

\section{REFERENCES}

1. Braun P, Wiesmann F. Phenotypic assays for the determination of coreceptor tropism in HIV-1 infected individuals. Eur J Med Res. 2007;12:463-72.

2. Chueca N, Garrido C, Alvarez M, Poveda E, de Dios Luna J, Zahonero N, et al. Improvement in the determination of HIV-1 tropism using the V3 gene sequence and a combination of bioinformatic tools. J Med Virol. 2009;81:763-7.

3. Delobel P, Nugeyre MT, Cazabat M, Pasquier C, Marchou B, Massip P, et al. Population-based sequencing of the $\mathrm{V} 3$ region of env for predicting the coreceptor usage of human immunodeficiency virus type 1 quasispecies. J Clin Microbiol. 2007; $45: 1572-80$

4. Delwart EL, Herring B, Rodrigo AG, Mullins JI. Genetic subtyping of human immunodeficiency virus using a heteroduplex mobility assay. PCR Methods Appl. 1995;4:S202-16.

5. Dybowski JN, Heider D, Hoffmann D. Prediction of co-receptor usage of HIV-1 from genotype. PLoS Comput Biol. 2010;6:e1000743.

6. Emmelkamp JM, Rockstroh JK. CCR5 antagonists: comparison of efficacy, side effects, pharmacokinetics and interactions--review of the literature. Eur J Med Res. 2007; 12:409-17.

7. Harrigan PR, Geretti AM. Genotypic tropism testing: evidence-based or leap of faith? AIDS. 2011;25:257-64

8. Hughes A, Nelson M. HIV entry: new insights and implications for patient management. Curr Opin Infect Dis. 2009;22:35-42.

9. Jensen MA, Li FS, van 't Wout AB, Nickle DC, Shriner D, He HX, et al. Improved coreceptor usage prediction and genotypic monitoring of R5-to-X4 transition by motif analysis of human immunodeficiency virus type 1 env V3 loop sequences. $\mathrm{J}$ Virol. 2003;77:13376-88.

10. Lengauer T, Sander O, Sierra S, Thielen A, Kaiser R. Bioinformatics prediction of HIV coreceptor usage. Nat Biotechnol. 2007;25:1407-10.

11. McGovern RA, Harrigan PR, Swenson LC. Genotypic inference of HIV-1 tropism using population-based sequencing of V3. J Vis Exp. 2010(46).pii:2531. doi: $10.3791 / 2531$.

12. Mild M, Kvist A, Esbjörnsson J, Karlsson I, Fenyo EM, Medstrand P. Differences in molecular evolution between switch (R5 to R5X4/X4-tropic) and non-switch (R5tropic only) HIV-1 populations during infection. Infect Genet Evol. 2010;10:356-64.
13. Paar C, Geit M, Stekel H, Berg J. Genotypic prediction of human immunodeficiency virus type 1 tropism from plasma and peripheral blood mononuclear cells in the routine clinical laboratory. J Clin Microbiol. 2011;49:2697-9.

14. Parra J, Portilla J, Pulido F, Sanchez-de la Rosa R, Alonso-Villaverde C, Berenguer J, et al. Clinical utility of maraviroc. Clin Drug Investig. 2011;31:527-42.

15. Pillai S, Good B, Richman D, Corbeil J. A new perspective on V3 phenotype prediction. AIDS Res Hum Retroviruses. 2003;19:145-9.

16. Prosperi MC, Fanti I, Ulivi G, Micarelli A, De Luca A, Zazzi M. Robust supervised and unsupervised statistical learning for HIV type 1 coreceptor usage analysis. AIDS Res Hum Retroviruses. 2009;25:305-14.

17. Raymond S, Delobel P, Mavigner M, Cazabat M, Souyris C, Sandres-Saune K, et al. Correlation between genotypic predictions based on V3 sequences and phenotypic determination of HIV-1 tropism. AIDS. 2008;22:F11-6.

18. Recordon-Pinson P, Soulie C, Flandre P, Descamps D, Lazrek M, Charpentier C, et al. Evaluation of the genotypic prediction of HIV-1 coreceptor use versus a phenotypic assay and correlation with the virological response to maraviroc: the ANRS GenoTropism study. Antimicrob Agents Chemother. 2010;54:3335-40.

19. Sander O, Sing T, Sommer I, Low AJ, Cheung PK, Harrigan PR, et al. Structural descriptors of gp120 V3 loop for the prediction of HIV-1 coreceptor usage. PLoS Comput Biol. 2007;3(3):e58.

20. Saracino A, Monno L, Cibelli DC, Punzi G, Brindicci G, Ladisa N, et al. Coreceptor switch during HAART is independent of virological success. J Med Virol. 2009;81:2036-44.

21. Seclén E, Garrido C, González M del M, González-Lahoz J, de Mendoza C, Soriano $\mathrm{V}$, et al. High sensitivity of specific genotypic tools for detection of $\mathrm{X} 4$ variants in antiretroviral-experienced patients suitable to be treated with CCR5 antagonists. J Antimicrob Chemother. 2010;65:1486-92.

22. Seclén E, Soriano V, González MM, Gómez S, Thielen A, Poveda E. High concordance between the position-specific scoring matrix and geno2pheno algorithms for genotypic interpretation of HIV-1 tropism: V3 length as the major cause of disagreement. J Clin Microbiol. 2011;49:3380-2.

23. Sierra S, Kaiser R, Thielen A, Lengauer T. Genotypic coreceptor analysis. Eur J Med Res. 2007;12:453-62

24. Sing T, Low AJ, Beerenwinkel N, Sander O, Cheung PK, Domingues FS, et al Predicting HIV coreceptor usage on the basis of genetic and clinical covariates. Antivir Ther. 2007;12:1097-106.

25. Tamura K, Peterson D, Peterson N, Stecher G, Nei M, Kumar S. MEGA5: molecular evolutionary genetics analysis using maximum likelihood, evolutionary distance, and maximum parsimony methods. Mol Biol Evol. 2011;28:2731-9.

26. Trabaud MA, Icard V, Scholtes C, Perpoint T, Koffi J, Cotte L, et al. Discordance in HIV-1 co-receptor use prediction by different genotypic algorithms and phenotype assay: intermediate profile in relation to concordant predictions. J Med Virol. 2012;84:402-13

27. Vandekerckhove LP, Wensing AM, Kaiser R, Brun-Vezinet F, Clotet B, De Luca $\mathrm{A}$, et al. European guidelines on the clinical management of HIV-1 tropism testing. Lancet Infect Dis. 2011;11:394-407.

28. Verhofstede C, Vandekerckhove L, Eygen VV, Demecheleer E, Vandenbroucke I, Winters B, et al. CXCR4-using HIV type 1 variants are more commonly found in peripheral blood mononuclear cell DNA than in plasma RNA. J Acquir Immune Defic Syndr. 2009;50:126-36.

Received: 28 July 2013

Accepted: 30 January 2014 